\title{
MANAGEMENT OF ECONOMIC SUSTAINABILITY OF THE ENTERPRISE
}

\section{Shmygol N.M., Kasianok M.A.}

Zaporizhzhia National University

Ukraine, 69600, Zaporizhzhia, Zhukovsky str., 66

nadezdash@ua.fm,mkasianok@gmail.com

\author{
ORCID 0000-0001-5932-6580, 0000-0002-8514-0672
}

\section{Key words:}

economic sustainability, stability, functional subsystem, sustainable development management.
The article reveals the problem of managing the economic stability of the enterprise as a basis for the economic security of the state. Theoretical provisions have been substantiated and practical recommendations are developed to improve financial stability in order to ensure the stable operation of the enterprise. The factors of the external and internal environment influencing the market conditions, efficiency and effectiveness of economic activity of enterprises have been described. On the basis of the integrated approach the main functional subsystems of the enterprise have been distinguished, which consist of: financial, production, technological, organizational, market (including price), social-ecological, investment and others. They have analysed the possibility of influencing the operation of each subsystem individually and creating the conditions for free manoeuvring of the cash of the enterprise and through their efficient use, as well as facilitating the continuous process of production and sale of products. The principles of formation and structure of algorithm of management of sustainable development of the enterprise have been formulated. Any assessment based on the calculation of quantitative indicators alone is not able to reveal the mechanism for supporting the sustainable development of the enterprise. It is also necessary to use qualitative indicators in addition to quantitative indicators, as this approach contributes to an in-depth understanding of the problem of economic stability of the enterprise. Formation of the algorithm of sustainable development of the enterprise should be carried out on the basis of the following principles: integrity - interconnectedness and subordination of all components of the system, complexity - requires consideration of all anticipated factors of influence, continuity - regulation of influence as new information is received, implementation of the regulatory process must be continuous. The adequacy is the conformity of the system with the natural reality. The main task of management is to develop a strategy that anticipates the future sustainable development of the enterprise, and then the gradual implementation and amendment of the chosen strategy through management and short-term planning.

\section{УПРАВЛІННЯ ЕКОНОМІЧНОЮ СТІЙКІСТЮ ПІДПРИЕМСТВА Шмиголь Н.М., Касянок М. А.}

Запорізький національний університет

Украӥна, 69600, м. Запоріжжя, вул. Жуковського, 66

\author{
Ключові слова: \\ економічна стійкість, стабільність, \\ функціональна підсистема, управління \\ сталим розвитком.
}

У статті розкрито проблему управління економічною стійкістю підприємства як основи економічної безпеки держави. Обгрунтувано теоретичні положення та розроблено практичні рекомендацій щодо підвищення фінансової стійкості задля забезпечення стабільної роботи підприємства. Описано фактори зовнішнього та внутрішнього середовища, що впливають на ринкові умови, ефективність i результативність економічної діяльності підприємств. На підставі комплексного підходу виділено основні функціональні підсистеми підприємства, до яких відносяться фінансова, виробнича, технологічна, організаційна, ринкова (включаючи цінову), соціально-екологічна, інвестиційна та ін. Проаналізовано можливість впливу роботи кожної підсистеми окремо та створення умов для вільного маневрування грошовими коштами підприємства і шляхом ефективного їх використання, а також сприяння безперервному процесу виробництва і реалізації продукції. Сформульовано принципи формування та структуру алгоритму управління стійким розвитком підприємства. Будь-яка оцінка, заснована на розрахунку тільки кількісних показників, не розкриває механізму підтримки сталого розвитку підприємства. Поряд 3 кількісними показниками необхідно також використовувати і якісні, оскільки такий підхід сприяє поглибленому розумінню проблеми розвитку економічної стійкості підприємства. Формування алгоритму стійкого розвитку підприємства повинно здійснюватися на основі таких принципів: цілісність - взаємопов'язаність і 
підпорядкованість усіх складових системи, комплексність - вимагає врахування всіх передбачуваних факторів впливу, безперервність регулювання впливу в міру надходження нової інформації, реалізація процесу регулювання повинна носити безперервний характер, адекватністьвідповідність системи закономірною дійсності. Реалізація процесу сталого розвитку будь-якого підприємства - певні логічні дії, спрямовані на вирішення проблем стійкості підприємства. Головним завданням керівництва $є$ розробка стратегії, яка передбачає майбутній стійкий розвиток підприємства, а далі-поетапну реалізацію і внесення поправок до обраної стратегії за допомогою управління і короткострокового планування.

\section{Statement of the problem}

The relevance of the research methods of ensuring and assessing the economic sustainability of the enterprise due to the fact that in conditions the modern economy, the company has a lot of various negative factors that may shake his stable and profitable existence. It is for the successful functioning of the enterprise that one should pay attention to this issue.

\section{Analysis of recent studies and publications}

The category "sustainability" is used by scientists in various fields of science (in biology, economics, mathematics, mechanics, psychology, sociology, technology, physics, chemistry), related to the study and operation of complex systems. The theory of stability of systems today is sufficiently developed in the general form, and is represented by the works of such scientists as G. Azoeva, P. Belenky, Z. Vasilyeva, O. Dzublyuk, V.Kovalenko, V. Kochetkov, N. Pertovsky etc. In recent decades, economists have been actively engaged in the stability mechanism.

The analysis of the sustainability of the enterprise showed that the research in this area is very intensive, but the researchers mainly focuse on its financial aspects. Although sustainability is a generic complex category, it cannot be limited to reflecting only one aspect of an entity's activities.

The investigation of the issue of economic stability of enterprises in terms of multivariate, interconnectedness and dynamism of factors of external and internal environment was dealt with by A. Afanasiev, V. Berens, O. Vasilenko, D. Gorodinski, A. Kuznetsov, E. Melnyk, M. Morishima, I. Omelchenko, U. Ouchy, O. Raevnev, V. Samulak, V. Semenov, Y. Simeh, S. Thor, R. Fatkhutdinov, E. Helfert and others. However, these scientists, considering the concept of "economic sustainability" of the enterprise, do not separately distinguish the stability of functioning and stability of development, often identify the concept of equilibrium and stability as characteristics of the economic system. The ambiguity and lack of coherence of scientists' views on defining the nature and content of the category "economic sustainability of the enterprise" and the only categorical base on this problem made the relevance of this research.

\section{Objectives of the article}

The purpose of the work is to substantiate theoretical provisions and to develop practical recommendations for improving economic stability to ensure the stable operation of the enterprise. To formulate principles of formation and structure of the algorithm of management of sustainable development of the enterprise.

\section{The main material of the research}

The foundation for economic security of any state is the effective development and functioning of the primary link of the economy - the enterprise. It is enterprises that have a primary influence on all components of the country's sustainable development and deserve special attention when studying the problem of economic sustainability.

There are many external and internal factors that actively influence the market conditions, efficiency and effectiveness of economic activity of enterprises. The environmental factors include:

- tax policy of the state;

- inflation;

- interest rate;

- State and legislative factors;

- scientific and technological progress;

- socio-cultural environment.

Internal factors include:

- production process;

- management system;

- financial policy;

- personnel composition;

- business reputation;

- marketing, etc.

Thus, economic stability is determined by the ability of an enterprise to develop dynamically under the influence of external and internal environments, while maintaining all production and economic indicators.

The ability to achieve the goals set by the enterprise, including sustainable economic development, depends more on the effectiveness of the decisions made. For this there is an urgent need to create an algorithm for managing enterprise sustainability.

Any organization is a complex multilevel system. The following can be distinguished as the main standalone autonomous subsystems:

- financially;

- production;

- technological;

- organizational; 
- market (including price);

- socio-ecological;

- investment and others.

The profitability and efficiency of the enterprise are affected by the consistency of all subsystems. As a result, it is necessary to analyse the impact of each subsystem separately.

The financial sustainability is a reflection of a stable excess of income over costs, creates conditions for free manoeuvring of the enterprise's cash resources and through their efficient use, and facilitates a continuous process of production and sales of products. As a result, financial sustainability is formed throughout the entire production and economic activity and is the first in importance, a component of the overall sustainability of the enterprise.

The stability of the financial subsystem is the efficiency of use of fixed and circulating assets, maintaining solvency and creditworthiness. In this regard, it is necessary to have such a state of financial resources, when effectively used by which the company is able to guarantee a smooth process of production and marketing of products and the opportunity to invest in the expansion and upgrade of production.

At the present stage, many papers dealt with in detail only "financial sustainability", which eliminates the possibility of carrying out an "integrated approach" to the assessment of economic sustainability.

A significant role in the sustainable development of manufacturing enterprises is played by the production subsystem. The stability of this functional area is determined by the presence of the potential, capable of providing break-even volume of production and increase of production profitability. Needs adjustment and stability of the production cycle of the enterprise, the sustainability of its resource supply.

In assessing the economic sustainability of manufacturing enterprises, it is also necessary to analyse the technological component, which is a complex of interconnected equipment, machines, automation, monitoring and control, as well as a set of technological processes of the main and auxiliary industries.

This subsystem does not consider the main assets of the enterprise, and analyses only those tools and tools that are directly involved in the implementation of production technologies.

The organizational stability reflects the stability of the internal organizational system, the flexibility of the management structure, forms and types of control, the establishment and efficiency of communications between different departments and services of the enterprise, the effectiveness and efficiency of their joint cooperation. The organizational structure can be considered stable provided that the system of management, allocation of decisionmaking powers is able to respond immediately to changes in the external and internal environment.
The main task of the company is to ensure the stable management of the structure and its reorganization. For example, the decline in the production process, caused by the outflow of personnel, can be compensated by the efficiency of the structure of the enterprise, which allows to reduce the reduction of part of the staff.

Any evaluation, as practice shows, based on the calculation of only quantitative indicators, is not able to reveal the mechanism of support for the sustainable development of the enterprise, based on management decisions, on informal, outside institutional relationships. It is also necessary to use qualitative indicators in addition to quantitative indicators, as this approach contributes to an in-depth understanding of the problem of the economic sustainability of enterprise development.

The marketing (market) resilience is a set of marketing strategies and tactics aimed at achieving the goals of the enterprise, namely: obtaining reliable and adequate specialized information on supply and demand in different market segments, the ability of the company to respond to irregular orders and reduce the risk of their occurrence, rating and business reputation enhancement. The stability of the marketing subsystem depends on:

- market factors, including market capacity;

- competition;

- elasticity of demand;

- the price policy of the state;

- other external factors.

A significant role is played by the positioning of the product of the enterprise in the minds of consumers, depending on how much they were previously satisfied with its purchase, as well as on the feedback of other buyers, the image of the company and the activity of its advertising campaigns [1, p. 92-95].

The stability of the enterprise according to the market competitiveness classifiers is characterized by:

- sales growth;

- market expansion;

- expansion of the sales network.

Here, a productive indicator is the market share that has been "captured" by the enterprise. The deviation of the share from the minimum allowable value will indicate a decrease in the stability of the competitiveness of the products of the enterprise.

In marketing sustainability, the most important component is price stability, which determines the ability of an enterprise to provide an optimal mechanism for product pricing, which allows for the highest efficiency to plan a sustainable level of profit.

An economic entity that seeks to become sustainable in pricing, sets prices that contribute to survival in market conditions, uses different pricing methods, develops a pricing system, selects pricing market strategies, etc.

There are two main aspects to price stability:

- ensuring survival (sales volume and market share); 
- profit maximization (elasticity of demand for price, level of internal costs, planning of stable level of profit).

Today, much of the scientific world's attention is driven to environmental sustainability. Most countries' economic policies take environmental aspects into account and work is underway to reduce the negative impact on the environment. There are many contradictions regarding the harmonious interaction of economic and environmental sustainability, indicating that economic interests do not meet environmental requirements.

The economic aspects of sustainable environmental development include:

- use of environmental technology;

- development of a development strategy that would help minimize costs for environmental development;

- replacement of cost-benefit system (based on the analysis of profits and losses from environmental pollution) by the principle of cost-effectiveness (necessity of costs for ensuring the efficiency of ecological production and reproduction) [3].

An important role in the development of the enterprise is played by investment stability, which promotes the investment activity of the organization at each individual interval in the conditions of uncertainty of the external and internal environment, which disrupt the normal development of the enterprise. Sustainable development of the enterprise is due to the implementation of effective investment projects. After the investments are made, the process of functioning of the enterprise for a time goes beyond the stationary regime, in order to move to another, qualitatively new, higher stationary mode of functioning.

Depending on the specific economic activity of the enterprise, it is necessary to distinguish all significant functioning subsystems that directly affect its overall stability.

In the process of managing the sustainable development of the enterprise, the main task of the management system is to identify various factors that affect its functionality and efficiency, and at the same time to use their influence in the areas required for the enterprise. The main goal - to positively influence the factors of sustainable development to their advantage.

In this regard, it is necessary to form an algorithm for sustainable development of the enterprise, which is a qualitatively new system aimed at improving its stability and functionality.

The essence of the sustainable development algorithm of an enterprise is that any enterprise is an open system, which is affected by factors of the internal and external environment.

The development of an enterprise sustainability management algorithm should be based on a systematic approach. Any business activity is a set of connections and dependencies, their realization, support and break of already existing connections. The process of functioning of the enterprise is represented by a set of indicators that reflect the performance of the activity.

Formation of the algorithm of sustainable development of the enterprise should be carried out on the basis of the following principles:

- integrity - interconnectedness and subordination of all components of the system;

- complexity - requires consideration of all anticipated factors of influence;

- continuity - regulation of influence as new information is received; the implementation of the regulatory process must be continuous;

- adequacy - conformity of the system with the natural reality.

Structural generators of sustainable enterprise development are factors of production, which are characterized by the quantity and quality of resources used; investment; innovative activity.

Depending on the factors that influence economic growth, they distinguish between extensive and intensive ways of economic development. With extensive development, an increase in production is due to an increase in the number of factors used. The intensive path of economic development is characterized by the improvement of technology and technology and the improvement of the quality of the main production factors.

In order to achieve the required level of sustainable development, an enterprise must provide a margin of sustainability by improving performance, using more intensive production factors. Sustainable development of production is based on the efficiency of the management policy of the enterprise, which includes the installation and use of modernized equipment and modern technologies. The sustainable development of the market functional zone includes an effective marketing strategy, conducting effective advertising companies, developing and increasing the range of products, introducing innovations. The stability of the financial subsystem is characterized by profitability indicators, which are the most important indicators of the financial condition of the enterprise.

\section{Conclusions}

The implementation of the process of sustainable development of any enterprise is certain logical actions aimed at solving the problems of sustainability of the enterprise. The main task of management is to develop a strategy that anticipates the future sustainable development of the company, and then the gradual implementation and amendment of the chosen strategy through management and short-term planning.

\section{References}

1. Antonyuk, G.Y. (2006). Zovnishni chynnyky konkurentospromozhnosti promyslovosti [External factors of competitiveness industry in the conditions]. Lviv: LKA [in Ukrainian]. 
2. Baranovskyj, O.I. (2011). Finansova bezpeka v Ukrayini (metodologiya ocinky ta mexanizmy zabezpechennya) [Financial security in Ukraine (valuation methodology and assurance mechanisms)]. Kyiv: Znannia [in Ukrainian].

3. Gadzevych, O.I. (2014). Osnovy ekonomichnogo analizu i diagnostyky finansovoyi diyalnosti pidpryyemstv [Fundamentals of economic analysis and diagnostics of financial activity of enterprises]. Kyiv: Kondor [in Ukrainian].

4. Dokiyenko, L.M. (2015). Udoskonalennya procesu upravlinnya finansovoyu stijkistyu pidpryyemstv promyslovosti yak neobxidna peredumova pidvyshhennya yix konkurentozdatnosti [Improving the process of financial stability management of industrial enterprises as a necessary prerequisite for increasing their competitiveness]. Kyiv: KNU [in Ukrainian].

5. Kyzym, M.O. (2013). Ocinka i diagnostyka finansovoyi stijkosti pidpryyemstva [Evaluation and diagnostics of financial stability of the enterprise]. Xarkiv: INZhEK [in Ukrainian].

6. Kosteczkyj, V.V. (2010). Sutnisno-teoretychni pidxody do vyznachennya finansovogo zabezpechennya diyalnosti pidpryyemstva [Essential-theoretical approaches to the definition of financial support for the activity of the enterprise]. Kyiv: KNU [in Ukrainian].

7. Kryvyczka, O.R. (2012). Planuvannya prybutku pidpryyemstva pry vyznachenni strategiyijogo rozvytku [Enterprise profit planning in determining its development strategy]. Kyiv: KNU [in Ukrainian].

8. Laryonov, Y.K. (2013). Antykryzysnoe upravlenye [Anti-crisis management]. Kyiv: Znannia [in Ukrainian].

9. Mizyuk, B.M. (2010). Strategichne upravlinnya [Strategic Management]. Lviv: Magnoliya plyus [in Ukrainian].

10. Samsonova, K.V. (2009). Faktory vplyvu na finansovu stijkist pidpryyemstva [Factors of influence on the financial stability of the enterprise]. Lviv: Magnoliya plyus [in Ukrainian].

11. Yalovyj, G.K. (2011). Konceptualni pidxody do vyznachennya finansovoyi stijkosti [Conceptual Approaches to Determining Financial Sustainability]. Kyiv: EksOb [in Ukrainian]. 